\title{
HOT ELECTRON DYNAMICS AND OPTICAL NONLINEARITIES IN NON-UNIFORMLY EXCITED INDIUM PHOSPHIDE
}

\author{
L. Subačius ${ }^{\mathrm{a}, \mathrm{b}}$ I. Kašalynas ${ }^{\mathrm{a}} \mathrm{M}$. Vingelis ${ }^{\mathrm{a}}$, and K. Jarašiūnas ${ }^{\mathrm{b}}$

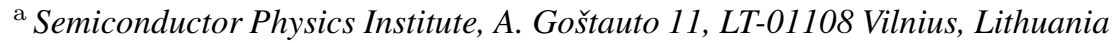 \\ E-mail: liudas@pfi.lt \\ ${ }^{\mathrm{b}}$ Institute of Materials Science and Applied Research, Vilnius University, Sauletekio 9, LT-10223 Vilnius, Lithuania
}

Received 23 November 2005

\begin{abstract}
Hot electron transport governed enhancement of light diffraction efficiency on transient grating has been observed in dcbiased semiinsulating InP:Fe crystal at below the energy gap excitation by picosecond laser pulses. Numerical analysis of dcfield-induced changes of free-carrier and electrooptic nonlinearities has been performed and allowed to attribute the observed effect to formation of a high-field domain grating, leading to dominant refractive index modulation by the quadratic electrooptic nonlinearity.
\end{abstract}

Keywords: nonlinear transport, optical nonlinearity, four-wave mixing, InP:Fe

PACS: $71.55 \mathrm{Eq}, 72.20 . \mathrm{Ht}$

\section{Introduction}

Photorefractive III-V semiconductors such as semiinsulating GaAs and InP exhibit features of infrared photosensitivity and negative differential resistivity (NDR) essential for high frequency devices and ultrafast semiconductor optoelectronics. To compensate for their low electrooptic (EO) coefficients, the application of high external electric field is used to enhance the photorefractive space-charge (SC) field resulting from the carrier transport in spatially modulated carrier pattern.

The recent studies of time-resolved four-wave mixing in dc-biased GaAs [1] pointed out the significance of hot electron transport effects for electrooptic refractive index modulation. At picosecond laser excitation and under applied high dc field in NDR region, the light-triggered domain instabilities lead to the SC field development and oscillations in $\mathrm{GHz}$ frequency range. Therefore, in highly excited photorefractive III$\mathrm{V}$ semiconductor, the high speed of hot electron intervalley transfer and short dielectric relaxation time lead to external field induced enhancement of non-resonant EO nonlinearity.

In this paper we extend the experimental and numerical studies of hot electron transport related optical nonlinearities in highly excited semi-insulating InP:Fe. We present the results of time-resolved degenerate four- wave mixing (DFWM) in dc-biased InP:Fe crystal at various external voltages, illumination intensities, and spatial periods of light interference pattern. The advanced hot electron hydrodynamic model is used to describe the experimentally observed peculiarities of nonlinear carrier transport in an optically modulated structure. We show that the non-uniform electron heating and the subsequent high-field domain formation result in enhancement of the four-wave mixing efficiency, thus confirming favourable conditions for the efficient and fast $\mathrm{EO}$ refractive index modulation.

\section{Experimental technique and model}

The photoexcited carrier transport in external electric field and its contribution to the optical nonlinearities were investigated experimentally and numerically. We applied the 30 ps duration laser pulses to modulate the refractive index by a light interference pattern in dcbiased InP:Fe crystal and to monitor the grating dynamics in configuration of DFWM. Gratings with spatial period of $\Lambda=10-50 \mu \mathrm{m}$ were recorded by Nd:YAG laser pulse at the wavelength $\lambda=1.06 \mu \mathrm{m}$ and full modulation depth of the light interference pattern.

In DFWM experiments, two interfering laser beams were combined in the bulk of the crystal to create a free carrier transient grating and to observe the first-order Bragg diffraction of the probe beam. The diffracted 
and transmitted probe beam intensities were measured by $\mathrm{Si}$ photodiodes, while the incident laser beam energy was controlled by a joulmeter. In this way, the time-dependent diffraction efficiency $\eta(t)$ and refractive index modulation $\Delta n(t)$, as well as contributions to the refractive index modulation by free carriers (FC), $\Delta n_{\mathrm{FC}}$, and electrooptic (EO) mechanism, $\Delta n_{\mathrm{EO}}$, were determined from the relationships

$$
\begin{aligned}
\eta= & \frac{I^{*}}{I_{\mathrm{T}}} \approx \sin ^{2}\left(\frac{\pi \Delta n d \lambda^{-1}}{\cos \theta}\right), \\
\Delta n= & {\left[\Delta n_{\mathrm{FC}}^{2}+\Delta n_{\mathrm{EO}}^{2}\right.} \\
& \left.+2 \Delta n_{\mathrm{FC}} \Delta n_{\mathrm{EO}} \cos \left(\Delta \phi_{\mathrm{FC}}-\Delta \phi_{\mathrm{EO}}\right)\right]^{1 / 2},
\end{aligned}
$$

here $I^{*}, I_{\mathrm{T}}$ are the intensities of the diffracted and transmitted beams, $d$ is the sample thickness, $\theta$ is the Bragg angle, $\Delta n_{\mathrm{FC}}, \Delta n_{\mathrm{EO}}$ and $\Delta \phi_{\mathrm{FC}}, \Delta \phi_{\mathrm{EO}}$ are the fundamental amplitudes and phases of the coexisting FC and EO gratings, respectively. We note, that in our experiment for the (001)-cut InP crystal that we use, the values of $\Delta n_{\mathrm{FC}}$ and $\Delta n_{\mathrm{EO}}$ have been calculated according to the relationships of the Drude-Lorentz model, $\Delta n_{\mathrm{FC}}=C_{\mathrm{FC}}\left[N / m^{*}+P / m_{p}\right]_{1}$, and quadratic EO effect, $\Delta n_{\mathrm{EO}}=C_{\mathrm{EO}}\left[E_{\text {int }}^{2}\right]_{1}$, where $N, m^{*}$ and $P$, $m_{p}$ are the densities and effective masses of electrons and holes, $C_{\mathrm{FC}}, C_{\mathrm{EO}}$ are the modulation coefficients, $E_{\text {int }}$ is the internal electric field, and the subscript "1" means the first Fourier component, which governs the light diffraction.

Nonlinear transport governed optical nonlinearities were studied by measuring the diffraction efficiency and subnanosecond kinetics of the grating decay at different excitation energies (in the range of photoexcited FC density from $10^{15}$ to $2 \cdot 10^{16} \mathrm{~cm}^{-3}$ ), different values of external dc field, and by varying the spatial period of light interference field. We used the $400 \mu \mathrm{m}$ thick samples with planar electrodes positioned at a $0.5-1 \mathrm{~mm}$ distance between them. The sample was connected with a segment of initially charged low impedance stripline that enabled us to create high electric field in the photoexcited crystal.

To simulate the resulting carrier dynamics and optical nonlinearities of light-induced grating, we used the photorefractive transport model of semi-insulating InP:Fe [2]. This model takes into account the influence of the excited $\mathrm{Fe}^{2+*}$ state and the interaction of the $\mathrm{Fe}^{2+} / \mathrm{Fe}^{3+}$ level with both the conduction and valence bands. For simplicity, we assumed that free carriers were excited mainly from the iron levels, while FC generation by band-to-band transitions was negligible at applied excitation energy below few $\mathrm{mJ} / \mathrm{cm}^{2}$. Using the material equations given below, which couple the continuity equations for two types of carriers with densities $N$ and $P$, the rate equation for ionized impurity with density $N_{\mathrm{i}}$, and the Poisson equation for electric field $E$, we calculated the instantaneous carrier-field distributions and extracted the amplitude and phase of the FC and EO gratings. For the one-dimensional case, these equations are:

$$
\begin{aligned}
\frac{\partial N}{\partial t}= & {\left[\beta_{n}+S_{n} I(h \nu)^{-1}\right] N_{a}+\left[\beta_{n}^{*}+S_{n}^{*} I(h \nu)^{-1}\right] N^{*} } \\
& -\left(\gamma_{n}+\gamma_{n}^{*}\right) n N_{0}-\gamma_{n p} n p+\frac{\partial\left(N v_{n}\right)}{\partial x}
\end{aligned}
$$

$$
\begin{aligned}
\frac{\partial P}{\partial t}= & {\left[\beta_{p}+\beta_{p}^{*}+\left(S_{p}+S_{p}^{*}\right) I(h \nu)^{-1}\right] N_{0}-\gamma_{p} p N_{a} } \\
& -\gamma_{p}^{*} p N^{*}-\gamma_{n p} n p-\frac{\partial\left(N v_{p}\right)}{\partial x}
\end{aligned}
$$

$$
\begin{aligned}
\frac{\partial N_{\mathrm{i}}}{\partial t}= & {\left[\beta_{p}+\beta_{p}^{*}+\left(S_{p}+S_{p}^{*}\right) I(h \nu)^{-1}\right.} \\
& \left.+\left(\gamma_{n}+\gamma_{n}^{*}\right) n\right] N_{0} \\
& -\left[\beta_{n}+S_{n} I(h \nu)^{-1}+\gamma_{p} p\right] N_{a} \\
& -\left[\beta_{n}^{*}+S_{n}^{*} I(h \nu)^{-1}+\gamma_{p}^{*} p\right] N^{*},
\end{aligned}
$$

$$
\frac{\partial E}{\partial x}=e\left(\varepsilon_{\mathrm{S}}\right)^{-1}\left(p-n-N_{\mathrm{i}}+N_{\mathrm{d}}\right),
$$

where $e$ is the electron charge, $\varepsilon_{\mathrm{S}}$ is the static dielectric constant of the material, $I$ is the intensity of the interference pattern, $h \nu$ is the photon energy, $N_{0}, N_{a}$, and $N^{*}$ are the densities of neutral $\mathrm{Fe}^{3+}$, ionized $\mathrm{Fe}^{2+}$, and excited $\mathrm{Fe}^{2+*}$ centres, $N_{\mathrm{i}}=\left[\mathrm{Fe}^{2+}\right]+\left[\mathrm{Fe}^{2+*}\right]$ is the ionized iron density, $N_{\mathrm{d}}$ is the density of residual shallow donors, and $v_{n}, v_{p}$ are the drift velocities of electrons and holes. In these equations, the symbols $S$, $\gamma$, and $\beta$ represent the photoionization cross-sections, recombination coefficients, and thermal emission rates, while the indices $n, p$, and $*$ stand for electron, hole, and excited $\mathrm{Fe}^{2+*}$ level.

The numerical studies are performed for the InP:Fe parameter values at $\lambda=1.06 \mu \mathrm{m}$, taken from literature to fit the diffraction efficiency measured in our sample without the external dc field. For carrier photogeneration from $\mathrm{Fe}^{2+}, \mathrm{Fe}^{3+}$, and $\mathrm{Fe}^{2+*}$, we used a similar set of the ionization cross-sections as in Ref. [3] 

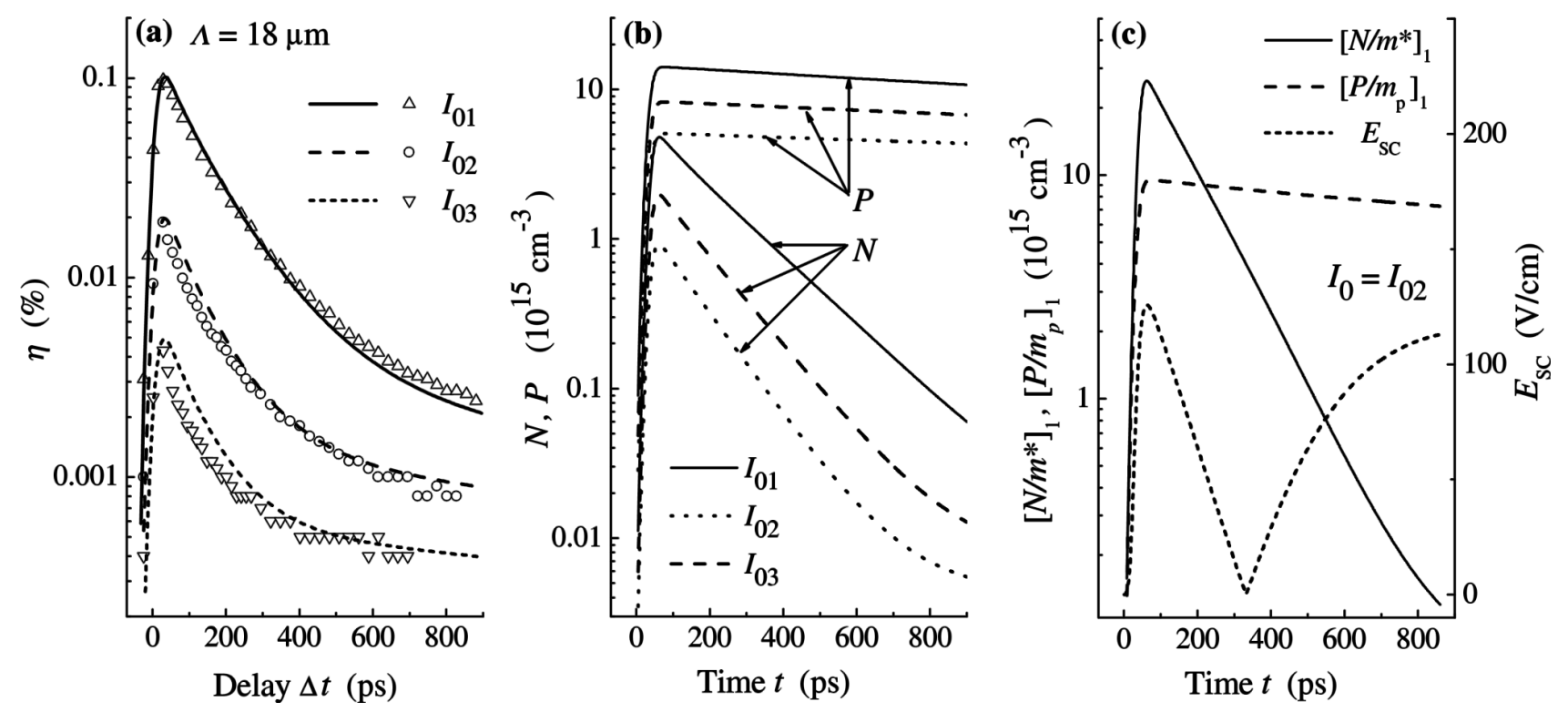

Fig. 1. (a) Comparison of the measured (points) and simulated (lines) kinetics of probe beam diffraction efficiency on $\Lambda=18 \mu \mathrm{m}$ grating and (b) the calculated time dependence of photogenerated carrier densities, observed for $E_{\mathrm{dc}}=0$ at relevant excitation energy $I_{0}, \mathrm{~mJ} / \mathrm{cm}^{2}: I_{01}=1.55, I_{02}=0.85, I_{03}=0.5$. (c) Time dependences of the fundamental harmonics of modulated electron and hole densities normalized to their effective masses (left-hand scale) and of the space-charge electric field (right-hand scale), calculated for $I_{02}=0.85 \mathrm{~mJ} / \mathrm{cm}^{2}$.

$\left(S_{n}=S_{p}+S_{p}^{*}=5 \cdot 10^{-17} \mathrm{~cm}^{2}, S_{p}=S_{n} / 3\right.$, and $S_{n}^{*}=5.35 \cdot 10^{-17} \mathrm{~cm}^{2}$ ), but slightly increased the iron density, $N_{a}=5 \cdot 10^{15} \mathrm{~cm}^{-3}$ and $N_{0}=4.5 \cdot 10^{16} \mathrm{~cm}^{-3}$. In order to fit the temporal evolution of diffraction efficiency, we used the following values of recombination and thermal emission rates: $\gamma_{n}=0.2 \cdot \gamma_{n}^{*}=$ $4.1 \cdot 10^{-8} \mathrm{~cm}^{3} / \mathrm{s}, \gamma_{p}=\gamma_{p}^{*}=1.6 \cdot 10^{-8} \mathrm{~cm}^{3} / \mathrm{s}$, $\gamma_{n p}=10^{-10} \mathrm{~cm}^{3} / \mathrm{s}$, and $\beta_{n}=10^{-8} \cdot \beta_{n}^{*}=10^{5} \cdot \beta_{p}=$ $10^{5} \cdot \beta_{p}^{*}=10 \mathrm{~s}^{-1}$.

\section{Results and discussion}

In Fig. 1(a), we present experimental and simulation results showing time dependences of probe beam diffraction efficiency in InP:Fe crystal, measured in the absence of external dc field $\left(E_{\mathrm{dc}}=0\right)$ for three different intensities of an exciting light pattern $I(x, t)=$ $I_{0}(t)[1+m \cos (2 \pi x / \Lambda)]$ with spatial period of $18 \mu \mathrm{m}$ and modulation depth $m \simeq 1$. The measured kinetics revealed a nonmonotonous grating decay with its initial relaxation time of about 200 ps. By the subsequent modelling we found that the observed subnanosecond dynamics is mainly determined by the peculiarities of FC generation, recombination, and hole-electron competition in a highly excited InP:Fe crystal.

The calculations of diffraction efficiency on coexisting electron and hole gratings, using the FC modulation coefficient value of $C_{\mathrm{FC}}=-3.5 \cdot 10^{-22} \mathrm{~cm}^{3}$, were found in rather good agreement with the measurements of DFWM (Fig. 1(a)). We notice that in our InP:Fe model the dominant carriers are holes and the density of photoexcited carriers varies with time (see Fig. 1(b)). Accordingly, the contributions of electron and hole gratings to the refractive index modulation, $\Delta n_{e}=C_{\mathrm{FC}}\left[N / m^{*}\right]_{1}$ and $\Delta n_{p}=C_{\mathrm{FC}}\left[P / m_{p}\right]_{1}$, also vary with time: initially the electrons contribute more significantly than the holes, while the hole grating becomes dominant at later time. This is demonstrated in Fig. 1(c). Also, in Fig. 1(c) we show the dynamics of SC field $E_{\mathrm{SC}}$ indicating that the fundamental harmonics of internal electric field peaks up to $\sim 120 \mathrm{~V} / \mathrm{cm}$, thus providing a few orders of magnitude smaller value of electrooptic refractive index modulation. Thus in highly excited InP:Fe at $E_{\mathrm{dc}}=0$, the refractive index modulation by EO effect is much smaller than that by the FC nonlinearity.

The effect of external electric field upon carrier transport was observed under the applied high dc field (at $E_{\mathrm{dc}}>10 \mathrm{kV} / \mathrm{cm}$ ) and resulted in an enhancement of diffraction efficiency (see Fig. 2). The experimental results demonstrated quite fast dynamics of the effect and a more efficient enhancement at large grating period or lower excitation intensities. The features of the effect allowed us to attribute its origin to the EO nonlinearity due to non-uniform electron heating and photorefractive domain grating formation in the region of 

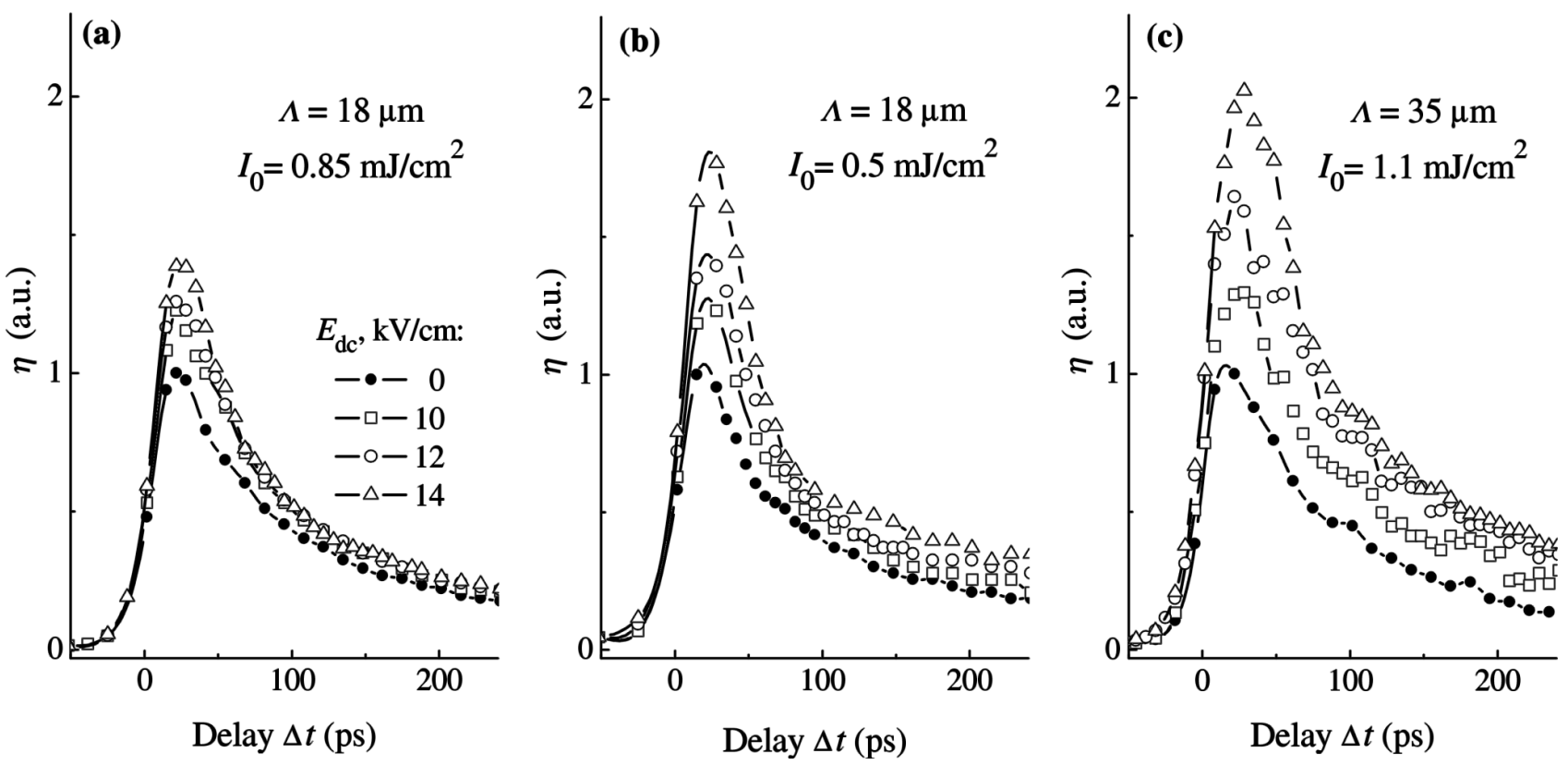

Fig. 2. Light diffraction efficiency versus probe beam delay, measured at different values of external dc field $E_{\mathrm{dc}}$, excitation energy $I_{0}$, and grating period $\Lambda$.

NDR [4, 5]. To confirm this hypothesis, the subsequent numerical analysis has been performed.

For numerical calculation, we used the advanced hydrodynamic model [5], which takes into account the non-uniform electron heating and intervalley transfer effects. In this model, the nonlinear transport and hot carrier dynamics in transient grating are described by the conservation equations for electron drift velocity $v(x, t)$ and mean energy $\varepsilon(x, t)$ :

$$
\begin{aligned}
& \frac{\partial v}{\partial t}=e \frac{E}{m^{*}}-v \nu_{v}-v \frac{\partial v}{\partial x}-\frac{1}{N} \frac{\partial\left(N Q_{v}\right)}{\partial x}, \\
& \frac{\partial \varepsilon}{\partial t}=e E v-\left(\varepsilon-\varepsilon_{0}\right) \nu_{\varepsilon}-v \frac{\partial \varepsilon}{\partial x}-\frac{1}{N} \frac{\partial\left(N Q_{\varepsilon}\right)}{\partial x},
\end{aligned}
$$

where $\varepsilon_{0}$ is the mean energy in thermodynamic equilibrium, $\nu_{v}$ and $\nu_{\varepsilon}$ are the velocity and energy relaxation rates, $Q_{v}=\left\langle\partial v^{2}\right\rangle_{0}$ is the variance of velocity-velocity fluctuations, and $Q_{\varepsilon}=\langle\partial v \partial \varepsilon\rangle_{0}$ is the covariance of velocity-energy fluctuations. Here brackets mean average over the hot carrier distribution function in momentum space, and the subscript " 0 " indicates steady-state conditions under applied voltage. All the parameters are obtained from the Monte Carlo simulations of InP crystal [5].

The plots in Fig. 3 allow us to compare the kinetics of diffraction efficiency, governed by FC nonlinearity and by quadratic EO effect at different values of external dc field. The simulation results show that the enhancement effect is present only at EO refractive index modulation: under external dc bias, the efficiency of
FC grating decreases (Fig. 3(a)), whereas the efficiency of EO grating is strongly enhanced during the illumination (Fig. 3(c)) and $\eta_{\mathrm{EO}} \gg \eta_{\mathrm{FC}}$ at $E_{\mathrm{dc}}=14 \mathrm{kV} / \mathrm{cm}$. This feature arises in dc-biased grating due to nonuniform electron heating and a high-field domain formation in regions with the negative differential resistivity.

The calculated instantaneous carrier density and internal electric field distributions revealed that the spatial modulation of internal electric field builds up in the non-illuminated areas as the external dc field is screened in the peaks of FC grating. At later time, with increasing the photoexcited carrier density, the increase of internal electric field value is expected due to nonuniform electron heating and field domain formation in each minima of the interference pattern. The plots in Fig. 3(b,d) demonstrate the external dc-field-induced changes of carrier density and internal field spatial distributions in dc-biased grating at the end of 30 ps duration laser pulse.

In conclusion, we investigated the nonlinear carrier transport governed non-resonant optical nonlinearity in dc-biased InP:Fe under the non-uniform excitation by ps laser beams. The external field-induced enhancement of light diffraction on transient grating was observed experimentally by using the time-resolved DFWM technique. Numerical analysis of hot electron dynamics and related optical nonlinearities allowed us to attribute the origin of the fast and efficient enhancement of diffraction efficiency to hot carrier transport 

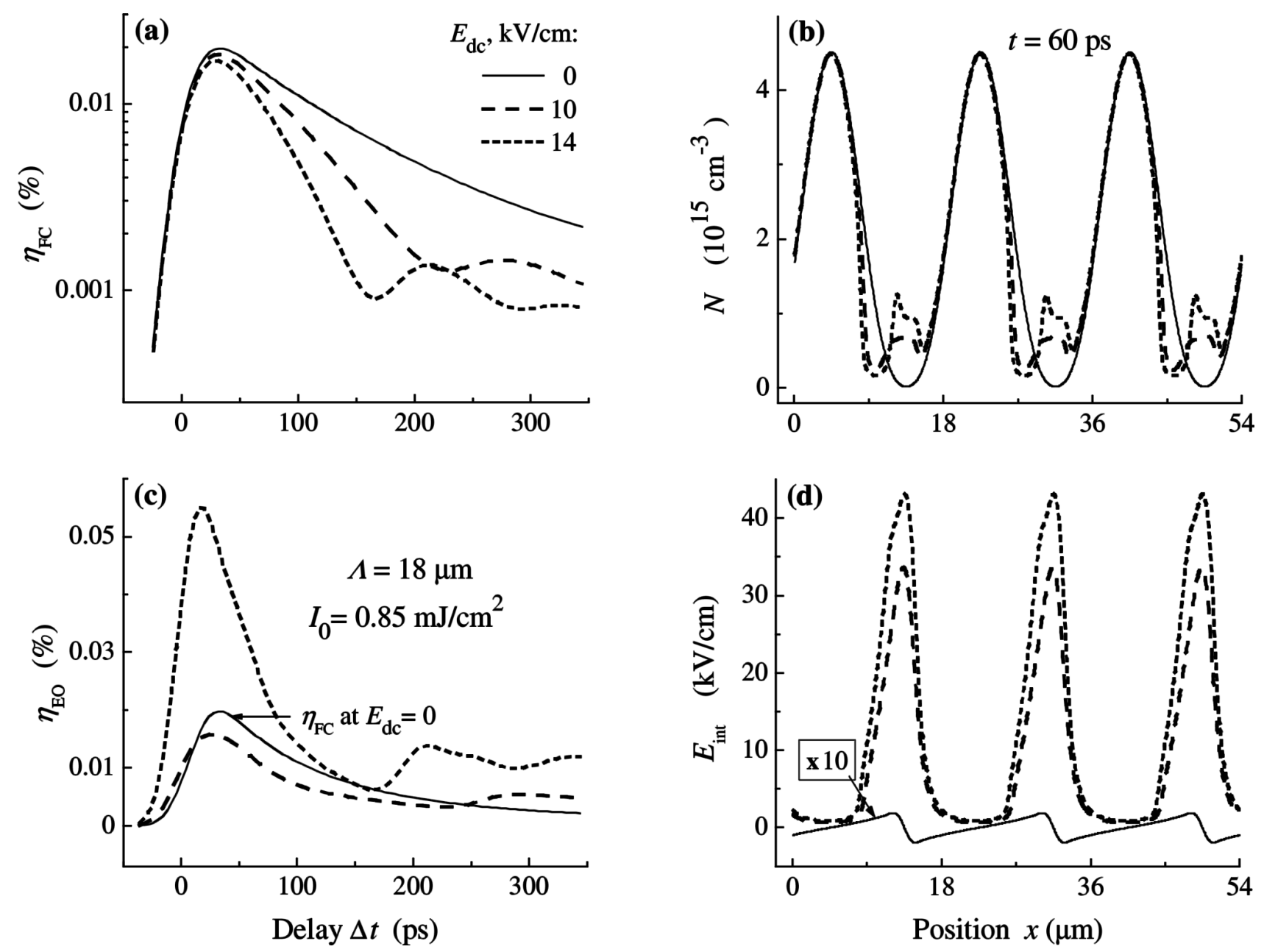

Fig. 3. The calculated kinetics of probe beam diffraction efficiency on (a) FC and (c) EO gratings, and the spatial distributions of (b) electron density and (d) internal electric field at $t=60 \mathrm{ps}$, simulated for different external dc field values. The EO coefficient value of $C_{\mathrm{EO}}=-3 \cdot 10^{-8} \mathrm{~cm}^{2} / \mathrm{kV}^{2}$ [1] was used for calculation of the quadratic EO nonlinearity.

governed formation of high-electric-field domains and subsequent quadratic EO refractive index modulation.

\section{Acknowledgement}

The work is partially supported by NATO's Scientific Affairs Division in the framework of the Science for Peace Programme (Project SfP-974476).

\section{References}

[1] L. Subačius, I. Kašalynas, R. Aleksiejūnas, and K. Jarašiūnas, Fast optical nonlinearity induced by space-charge waves in dc-biased GaAs, Appl. Phys. Lett. 83(8), 1557-1559 (2003).
[2] P. Delaye, P.U. Halter, and G. Roosen, Continuouswave two-beam coupling in InP:Fe and GaAs: evidence for thermal hole-electron competition in InP:Fe, J. Opt. Soc. Am. B 7(12), 2268-2273 (1990).

[3] P.U. Halter, J.C. Fabre, and G. Roosen, Induced nanosecond absorption in InP:Fe, IEEE J. Quant. Electron. 26(8), 1425-1433 (1990).

[4] L. Subačius, V. Gružinskis, E. Starikov, P. Shiktorov, and K. Jarašiūnas, Light diffraction on Gunn-domain gratings, Phys. Rev. B 55(19), 12844-12847 (1997).

[5] L. Subačius, E. Starikov, P. Shiktorov, V. Gružinskis, and K. Jarašiūnas, Hot carrier transport governed nonresonant optical non-linearity: Transient Gunn-domain grating, J. Opt. Soc. Am. B 15(7), 2045-2056 (1998). 


\title{
KARŠTŲJŲ KRŪVININKŲ DINAMIKA IR OPTINIAI NETIESIŠKUMAI NEVIENALYČIAI SUŽADINTAME INDŽIO FOSFIDE
}

\author{
L. Subačius ${ }^{a, b}$, I. Kašalynas ${ }^{a}$, M. Vingelis ${ }^{a}$, K. Jarašiūnas ${ }^{b}$ \\ a Puslaidininkiu fizikos institutas, Vilnius, Lietuva \\ ${ }^{\mathrm{b}}$ Vilniaus universiteto Medžiagotyros ir taikomuju mokslu institutas, Vilnius, Lietuva
}

\section{Santrauka}

Keturbangio maišymo būdu ištirtas karštuju krūvininku pernašos sukeltas netiesiškas optinis atsakas nevienalyčiai sužadintame InP:Fe kristale stipriame nuolatinès srovès elektriniame lauke. Matavimai atlikti pikosekundine keturbangio maišymo metodika, varijuojant interferencinio šviesos srauto energiją, dinaminès gardelès periodą ir išorinio elektrinio lauko stiprį. Eksperimentiškai aptiktas difrakcijos efektyvumo padidejimas (iki 2-3 kartų) ir nustatytas stipraus elektrinio lauko domenu susidarymas dinaminejje gardelèje dèl neigiamo diferencialinio laidumo. Modeliniais skaičiavimais ištirta karštụjų krūvininku dinamika optiškai moduliuotame InP:Fe ir įvertinti karštųu elektronų pernašos sukelti lūžio rodiklio pakitimai laisvụjų krūvininkų bei elektrooptinèje gardelèse. Skaičiavimo rezultatai paaiškina eksperimentiškai stebètus optinius netiesiškumus ir ju ypatumus stipriame elektriniame lauke. 